\title{
Impact of Technological Demonstrations on Yield of Rabi Pulses and Farmer's Adoption Behavior in Vindhyan Plateau of Madhya Pradesh
}

\author{
A.K. Singh ${ }^{1}$, Mamta Singh ${ }^{2}$, A.K. Tripathi ${ }^{2}$ and K.S. $\operatorname{Yadav}^{2}$ \\ ${ }^{1}$ Krishi Vigyan Kendra, Jawaharlal Nehru Agricultural University Jabalpur (MP), India \\ ${ }^{2}$ Jawaharlal Nehru Agricultural University, Krishi Vigyan Kendra, Sagar (MP), India \\ *Corresponding author
}

\section{Keywords \\ Frontline demonstrations; Impact, Adoption, Technology gap, Technology index \\ Article Info \\ Accepted: \\ 22 January 2019 \\ Available Online: \\ 10 February 2019}

\section{A B S T R A C T}

The important extension techniques to persuade the farmers about latest farm technologies are frontline demonstrations (FLDs). The present study was conducted continuously during three years from rabi 2015-16 to 2017-18 to assess the impact of 410 frontline demonstrations conducted on chickpea and lentil in 164 ha area across thirteen villages of Sagar district of Madhya Pradesh falls under Vindhyan Plateau Agro Climatic Zone. The results of demonstrations showed that farmers could increase the chickpea and lentil productivity remarkably by switching over to improved variety and adoption of improved production technology. It was observed from the FLDs that the improved chickpea variety JG 63 recorded the higher seed yield $\left(1537 \mathrm{~kg} \mathrm{ha}^{-1}\right)$ compared to the farmers' practices variety $\left(992 \mathrm{~kg} \mathrm{ha}^{-1}\right)$. The increase in the demonstration yield over farmer's practices was 55.27 percent. In case of lentil technology demonstrations, the average seed yield was recorded to be $1218 \mathrm{~kg} \mathrm{ha}^{-1}$ using JL 3, PL 8 and IPL 316 varieties over farmer's practice $\left(737 \mathrm{~kg} \mathrm{ha}^{-1}\right)$ with the average increase of 64.45 percent. The overall impact of frontline demonstrations on adoption of chickpea and lentil production technology was 461 and 334 percent respectively. It was noticed from the front line demonstrations conducted on chickpea and lentil that the average technology gap values were 663 and $282 \mathrm{~kg} \mathrm{ha}^{-1}$ respectively. The technology index was recorded to be 30.12 and 18.82 percent respectively in chickpea and lentil which reflect the superior performance of demonstrations.

\section{Introduction}

In India pulses are an integral part of the average human meal. A large proportion of the Indian population is vegetarian, and pulses form the main and affordable source of protein and minerals which play a key role in alleviating the protein calorie malnutrition, micronutrients deficiencies and other undernourishment related issues. These characteristics make pulses one of the cheapest sources of protein for human consumption. Protein malnutrition is prevalent among men, women and children in the country. Pulses contribute $11 \%$ of the total intake of proteins in India (Reddy, 2010). 
Additionally, pulses are a vital source of livelihood generation for millions of resource. Based on a study, Singh et al., (2018) reported that cultivation of pulses requires ten times less water than producing the same quantity of animal meat, moreover pulses not only fix atmospheric nitrogen to the extent of $70-210 \mathrm{~kg} \mathrm{ha}^{-1}$ but also lower carbon footprint because of low carbon emission and higher carbon sequestration.

Mostly the agriculture is being practiced by the poor farmers in semi-arid and sub-tropical regions of the country. Pigeonpea, chickpea, greengram, blackgram and lentil are the major pulse crops grown in large areas. Shortfall of pulses production potential has been attributed to a number of factors, the major ones being the increasing population, inadequate transfer of appropriate technology, seed longevity, poor seed quality, geographical shift, abrupt climatic changes, complex diseases, pest and socioeconomic conditions (Ali and Gupta, 2012). India accounts for $33 \%$ of the world area and $22 \%$ of the world production of pulses. About $90 \%$ of the global pigeon pea, $65 \%$ of chickpea and $37 \%$ of lentil area falls in India, corresponding to $93 \%, 68 \%$ and $32 \%$ of the global production, respectively (FAO STAT, 2012). In India pulses were grown in $23.5 \mathrm{~m}$ ha area with production of 172 million tonne in the year 2015-16 and productivity was 728 $\mathrm{kg} \mathrm{ha}^{-1}$ (Annual Report of Pulses, 2015-16). According to agriculture statistics 2014-15, chickpea, pigeonpea, greengram, blackgram and lentil was grown in 8.25, 3.55, 3.02, 3.24 and 1.47 million ha with the production of $7.33,2.78,1.5,1.96$ and 1.03 million tonne respectively in the country.

As a result of stagnant pulse production and continuous increase in population, the per capita availability of pulses has decreased considerably. The major constraints in pulse production are inadequate supply of quality seeds, low SRR, insufficient use of inputs, cultivation mostly under rainfed conditions as more than $87 \%$ of the area under pulses is presently rainfed which reported by Singh et al., (2018), biotic and abiotic stress, technology gap, lack of attractive market price, lack of proper procurement and poor storage facilities of the farm produce. Drought stress alone may reduce seed yields by $50 \%$ in the tropics as reported by Saxena et al., (2000). Keeping in view the shortfall in pulses production potential due to various factors listed above, Krishi Vigyan Kendra, Sagar (MP) conducted technology demonstrations on rabi pulses i.e. chickpea and lentil to enhance the production potentials and minimize the yield gap in the region.

\section{Materials and Methods}

The various technology components to be demonstrated for chickpea and lentil were identified based on group discussion. A cluster of similar farmers was identified based on their response and feedback received during the survey and group discussion. The technology demonstrations were conducted in Rehli, Jaisinagar, and Rahatgarh blocks of Sagar district during 2015-16 to 2017-18. A total of 410 farmers from 13 villages namely Channua, Parasia (Rehli block), Peepra, Kishanpura, Manak Chowk, Harbanshpura, Dhagrania, Maneshiya, Norza, Khajuria (Rahatgarh block), Hansrai, Masurhai and Semra Gopalman (Jaisinagar block). The farmer's practices were considered as control plot in all demonstrations. All inputs based on identified technology components viz seed, seed treatment materials i.e. fungicide (carboxin + thiram), biofertilizers - phosphate solubilizing bacteria (PSB) and Rhizobium, Trichoderma viridae for soil application @ $2.5 \mathrm{~kg} \mathrm{ha}^{-1}$ and need based insecticides were provided to the beneficiaries. Soil test based fertilizer nutrients for NPKS @ 20:60:20:20 $\mathrm{kg} \mathrm{ha}^{-1}$ in chickpea and NPKS @ 20:50:20:20 
$\mathrm{kg} \mathrm{ha} \mathrm{ha}^{-1}$ in lentil was applied. The demonstration plots were supervised by the KVK scientists during the crop period. The data of the demonstrations was collected and used to assess the impact on yield, adoption and varietal replacement. The data regarding adoption was collected from the farmers with the help of interview schedule. The demonstrations were undertaken in cluster approach in the selected villages with the objective to demonstrate the better production potentials and benefits of the latest improved technologies; to enhance the productivity of pulses in the region and to make farmers self sufficient in production of quality seed. Data were subjected to suitable statistical methods suggested by Samui et al., (2000) which is given below:

Technology gap = potential yield demonstration yield

Extension gap $=$ demonstration yield farmer's practices yield

Technology index $(\%)=$ potential yield demo yield / potential yield $x 100$

While impact on yield and impact on adoption was calculated by following formula-

Impact on yield $(\%)=$ yield of demo plot yield of check plot / yield of check plot x 100 Impact on adoption $(\%)=$ number of adopters after demo - number of adopters before demo/ number of adopters before Demo x 100

\section{Results and Discussion}

\section{Impact of frontline demonstrations on yield}

The findings related to impact of FLDs on yield are presented in table 1 and 2 . It is evident from table 1 that there was remarkable increase in yield of chickpea which was noted to be 43.34, 69.28 and 53.19 percent in the year 2015-16, 2016-17 and 2017-18 respectively with the mean value of 55.27 percent. The seed yield of chickpea in demonstrated plot was 1250 (2015-16), 1444
(2016-17) and $1918 \mathrm{~kg} \mathrm{ha}^{-1}$ (2017-18) with the pooled yield of $1537 \mathrm{~kg} \mathrm{ha}^{-1}$ over farmer's practice $\left(992 \mathrm{~kg} \mathrm{ha}^{-1}\right)$. This showed the significant increase in yield of chickpea over control. Yield enhancement in the different crops in frontline demonstration was reported by Tiwari et al., (2003), Tomar et al., (2003), Mishra et al., (2009) and Naberia et al., (2015). The trend was similar in case of lentil technological demonstrations (Table 2), revealed that the yield of demonstration plots of lentil was 948 (2015-16), 1401 (2016-17) and $1304 \mathrm{~kg} \mathrm{ha}^{-1}$ (2017-18) with the average yield of $1218 \mathrm{~kg} \mathrm{ha}^{-1}$ in comparison to farmer's practice $\left(737 \mathrm{~kg} \mathrm{ha}^{-1}\right)$. There was considerable increase in yield of lentil which recorded to be $39,87.666 .78$ percent for the year 2015-16, 2016-17 and 2017-18 respectively with the average increase of 64.45 percent. This show the positive impact of frontline demonstrations conducted on lentil in the region. The yield level of check plot was threatened due to low yielding local / old variety degenerated seeds, imbalanced fertilizer application and improper plant populations. However, in case of demonstration plots, the factors led to enhance the yield of demonstrated crops were, use of recommended wilt resistant high yielding variety, balanced dose of fertilizer nutrients and soil application of Trichoderma viridae@2.5 kg ha-1 for management of soil born diseases especially wilt and dry root rot.

\section{Impact on adoption}

Impact of FLDs on adoption of chickpea and lentil production technology by the farmers is presented in Table 3 and 4 respectively. It was found that adoption of high yielding wilt resistant variety of chickpea by the farmers was less before demonstration which was increased by 829 percent after conducting demonstrations due to availability of the quality seed of the demonstrated variety. Seed treatment with carboxin+thiram, PSB and 
Rhizobium was increased by 1589 percent due to technology interventions undertaken in the FLDs. Adopters in seed rate, fertilizer management and irrigation management were significantly increased by 1076 percent. Under lentil production technology the overall adoption level of various technology components was increased by 334 percent and 107 adopters were increased after conducting the technology demonstrations. Similar results were also reported by Chapke (2012) and Mahesh et al., (2016) (Table 5).

Table.1 Impact of frontline demonstration on yield of chickpea

\begin{tabular}{|c|c|c|c|c|c|c|}
\hline Year & Variety & $\begin{array}{c}\text { No. of } \\
\text { Farmers }\end{array}$ & Area (ha) & \multicolumn{2}{|c|}{ Average yield $\left(\mathbf{k g ~ h a}^{-\mathbf{1}}\right)$} & \multicolumn{1}{|c|}{$\begin{array}{c}\text { Impact (\% change } \\
\text { in yield) }\end{array}$} \\
\cline { 1 - 3 } & & & & FP & RP & \\
\hline $\mathbf{2 0 1 5 - 1 6}$ & JG 63 & 75 & 30 & 872 & 1250 & 43.34 \\
\hline $\mathbf{2 0 1 6 - 1 7}$ & JG 63 & 75 & 30 & 853 & 1444 & 69.28 \\
\hline $\mathbf{2 0 1 7 - 1 8}$ & JG 63 & 75 & 30 & 1252 & 1918 & 53.19 \\
\hline & Total & 225 & 90 & 992 & 1537 & 55.27 \\
\hline
\end{tabular}

Table.2 Impact of frontline demonstration on yield of lentil

\begin{tabular}{|c|c|c|c|c|c|c|}
\hline Year & Variety & $\begin{array}{c}\text { No. of } \\
\text { Farmers }\end{array}$ & Area (ha) & \multicolumn{2}{|c|}{ Average yield (kg ha $\left.{ }^{-1}\right)$} & $\begin{array}{c}\text { Impact (\% change in } \\
\text { yield) }\end{array}$ \\
\cline { 3 - 6 } & & & & FP & RP & \\
\hline $\mathbf{2 0 1 5 - 1 6}$ & JL 3 & 60 & 24 & 682 & 948 & 39.0 \\
\hline $\mathbf{2 0 1 6 - 1 7}$ & PL 8 & 75 & 30 & 747 & 1401 & 87.81 \\
\hline $\mathbf{2 0 1 7 - 1 8}$ & IPL 316 & 50 & 20 & 782 & 1304 & 66.75 \\
\hline & Total & 185 & 74 & 737 & 1218 & 64.45 \\
\hline
\end{tabular}

Table.3 Impact of frontline demonstrations on adoption of chickpea production technology

\begin{tabular}{|l|c|c|c|c|}
\hline \multicolumn{1}{|c|}{ Technology } & \multicolumn{2}{|c|}{ No. of adopter (225) } & $\begin{array}{c}\text { Change in No. } \\
\text { of adopter }\end{array}$ & $\begin{array}{c}\text { Impact } \\
\text { (\% change) }\end{array}$ \\
\cline { 2 - 5 } & $\begin{array}{c}\text { Before } \\
\text { Demonstration }\end{array}$ & $\begin{array}{c}\text { After } \\
\text { Demonstration }\end{array}$ & 109 & 232 \\
\hline $\begin{array}{l}\text { Application of } \\
\text { FYM }\end{array}$ & 47 & 156 & 174 & 829 \\
\hline $\begin{array}{l}\text { Recommended } \\
\text { variety }\end{array}$ & 21 & 195 & 161 & 894 \\
\hline $\begin{array}{l}\text { Seed rate (75 kg) } \\
\text { Seed treatment } \\
\text { (Fungicide, PSB, } \\
\text { Rhizobium) }\end{array}$ & 18 & 179 & 143 & 1589 \\
\hline $\begin{array}{l}\text { Fertilizer } \\
\text { management }\end{array}$ & 9 & 152 & 154 & 2200 \\
\hline $\begin{array}{l}\text { Irrigation } \\
\text { management }\end{array}$ & 86 & 161 & 115 & 134 \\
\hline Overall impact & 31 & 201 & 143 & 461 \\
\hline
\end{tabular}


Table.4 Impact of frontline demonstrations on adoption of lentil production technology

\begin{tabular}{|c|c|c|c|c|}
\hline \multirow[t]{2}{*}{ Technology } & \multicolumn{2}{|c|}{ No. of adopter (185) } & \multirow{2}{*}{$\begin{array}{c}\text { Change in No. of } \\
\text { adopter }\end{array}$} & \multirow{2}{*}{$\begin{array}{c}\text { Impact } \\
(\% \text { change })\end{array}$} \\
\hline & $\begin{array}{c}\text { Before } \\
\text { Demonstration }\end{array}$ & $\begin{array}{c}\text { After } \\
\text { Demonstration }\end{array}$ & & \\
\hline $\begin{array}{l}\text { Application of } \\
\text { FYM }\end{array}$ & 31 & 116 & 85 & 275 \\
\hline $\begin{array}{l}\text { Recommended } \\
\text { variety }\end{array}$ & 17 & 153 & 136 & 802 \\
\hline Seed rate $(40 \mathrm{~kg})$ & 19 & 142 & 123 & 649 \\
\hline $\begin{array}{l}\text { Seed treatment } \\
\text { (Fungicide, PSB, } \\
\text { Rhizobium) }\end{array}$ & 14 & 132 & 118 & 846 \\
\hline $\begin{array}{l}\text { Fertilizer } \\
\text { management }\end{array}$ & 11 & 126 & 115 & 1042 \\
\hline $\begin{array}{l}\text { Irrigation } \\
\text { management }\end{array}$ & 101 & 162 & 61 & 60 \\
\hline Overall impact & 32 & 139 & 107 & 334 \\
\hline
\end{tabular}

Table.5 Impact of frontline demonstrations on varietal replacement in cluster villages

\begin{tabular}{|l|l|l|}
\hline \multicolumn{1}{|c|}{ Crop } & \multicolumn{1}{|c|}{ Previously grown variety } & \multicolumn{1}{c|}{ New varieties introduced } \\
\hline Chickpea & Ujjain 21, JG 315, JG 322 & JG 63 \\
\hline Lentil & Local unidentified mixed seed & JL 3, PL 8, IPL 316 \\
\hline
\end{tabular}

Table.6 Seed yield, extension gap, technology gap and technology index of cluster frontline demonstrations on chickpea and lentil (pooled analysis of three year data from 2015-16 to 2017-

18)

\begin{tabular}{|c|c|c|c|c|c|c|c|}
\hline Crop & $\begin{array}{l}\text { No. of } \\
\text { FLDs }\end{array}$ & $\begin{array}{c}\text { Potential } \\
\text { yield } \\
\left(\mathrm{kg} \mathrm{ha}^{-1}\right)\end{array}$ & $\begin{array}{c}\text { Average } \\
\text { Demo } \\
\text { Yield } \\
\left(\mathrm{kg} \mathrm{ha}^{-1}\right)\end{array}$ & $\begin{array}{l}\text { Average } \\
\text { FP yield } \\
\text { (kg ha }^{-1} \text { ) }\end{array}$ & $\begin{array}{c}\text { Extension } \\
\text { gap } \\
\left(\mathrm{kg} \mathrm{ha}^{-1}\right)\end{array}$ & $\underset{\substack{\text { Tap } \\
\left(\mathrm{kg} \mathrm{ha}^{-1}\right)}}{ }$ & $\begin{array}{l}\text { Technology } \\
\text { index }(\%)\end{array}$ \\
\hline Chickpea & 225 & 2200 & 1537 & 992 & 545 & 663 & 30.12 \\
\hline Lentil & 185 & 1500 & 1218 & 737 & 481 & 282 & 18.82 \\
\hline
\end{tabular}

Impact of FLDs on varietal replacement in adopted villages

The FLDs include a technology package for making change in existing farmer's practices. It was found that the local / old or unidentified variety degenerated seeds of lentil were replaced by JL 3, PL 8 and IPL 316 in FLD clusters. While in chickpea, old varieties such as Ujjain 21, JG 315 and JG 322 were replaced by JG 63 a high yielding wilt resistant variety. Replacement of local/ old or unidentified varieties with new varieties of maize, paddy and wheat due to laying out the FLDs was reported by Balai et al., (2013). The data given in table 6 indicated that the technology index shows the feasibility of the evolved technology at 
farmer's field. Higher technology index reflected the insufficient extension services for transfer of technology. The lower value of technology index shows the efficacy and excellent performance of technological interventions. The average technology index in chickpea was observed to be 30.12 percent and in lentil it was 18.82 percent. Similar results were also reported by Singh et al., (2012), Diwivedi et al., (2014) and Tomar et al., (2003).

On the basis of the above findings it may be concluded that the frontline demonstrations enhanced the yield of crops vertically and ensured rapid spread of technologies horizontally. The technological demonstrations made positive and significant impact on enhancement of chickpea seed yield by 55.27 percent and lentil by 64.45 percent. It was found that the demonstrations are proven extension interventions to demonstrate the production potential of various crops on farmer's field. This may help to raise the pulses productivity at regional as well as state and national level.

\section{Acknowledgement}

Authors are thankful to Agricultural Technology Application Research Institute (Indian Council of Agricultural Research), Zone-IX, Jabalpur (MP) for providing necessary budget to conduct the frontline demonstrations on chickpea and lentil with the intend to raise the productivity and livelihood.

\section{References}

Ali, M. and Gupta, S. (2012). Carrying capacity of Indian agriculture: Pulse crop. Current Science, 102(6): 874-881.

Annual Report (2016). Directorate of Pulses Development, Ministry of agriculture \& Farmers Welfare (Department of
Agriculture, Cooperation \& Farmers Welfare, GoI), Vindhyachal Bhavan Bhopal (MP). DPD/Pub/TR/11/201516. pp. 71.

Balai, C.M., Bairwa, R.K., Vema, L.N., Roat, B.L. and Jalwania, R. (2013). Economic impact of front line demonstrations on cereal crop in Tribal belt of Rajasthan. International Journal of Agricultural Sciences, 3(7): 566-570.

Chapke, R.R. (2012). Impact of Front Line Demonstrations on jute (Corchorus olitorius). Journal of Human Ecology, 38(1): 37-41.

Diwivedi, A.P., Mishra A., Singh, S.K., Singh S.R.K. and Singh, M. (2014). Yield gap analysis of chickpea through frontline demonstration in different agroclimatic zone of M.P. and Chhatisgarh. Journal of Food Legume, 27(1): 60-63.

FAO STAT 2012. FAO statistical yearbook 2012. Food and agriculture organization of the United Nations, Rome 2012.

Ishwar Singh, D.S. Tomar, M.V. Mahajan, D.S. Nehte, Lakhan Singh and Singh, H.P. (2018). Impact of Front Line Demonstration on Chickpea to Meet the Deficit Pulse Availability in Malwa Plateau and Central Plateau Region of India. International Journal of Current Microbiology and Applied Sciences, 7(02): 2305-2311. doi: https://doi.org/10.20546/ijcmas.2018.70 2.279

Mahesh, M., Patil, S. and Chavan, A. (2016). Impact of FLD intervention on yield, adoption and horizontal spread of oilseed crop in Konkan. Indian Journal of Extension Education, 52(2\&3): 7983.

Mishra, D.K., Paliwal, D.K., Tailor, R.S. and Deshwal, A.K. (2009). Impact of front line demonstrations on yield enhancement of potato. Indian Research Journal of Extension Education, 9(3): 26-29. 
Naberia, S., Gautam, U.S. and Gupta, A.K. (2015). Psychological characteristics affecting the adoption of Agricultural Technologies, Indian Journal of Extension Education, 51(3\&4): 130132.

Reddy, A.A. (2010). Regional Disparities in Food Habits and Nutritional intake in Andhra Pradesh, India, Regional and Sectoral Economic Studies, Vol. 10-2.

Samui, S.K., Moitra, S., Roy, D.K., Mondal, A.K. and Saha, D. (2000). Evaluation of front line demonstration on groundnut (Arachis hypogeae L.) in Sunderban. Journal of Indian Society of Coastal Agricultural Research, 18(2): 180-183.

Saxena, K.B., D.P. Srivastava and S.B.S. Tikka (2000). Breaking Yield Barriers in Pigeon pea through Hybrid Breeding. In: M Ali, A N Asthana, Y S Rathore, S
N Gurha, S K Chaturvedi and S Gupta (ed.), Advances in Management of Biotic and Abiotic Stresses in Pulse Crops, Indian Institute of Pulses Research, Kanpur, pp 211-19.

Singh, R.P., Singh, A.N., Diwivedi, A.P., Mishra, A. and Singh, M. (2012). Assessment of yield gap in chickpea through frontline technology. Journal of Extension Education, 17(1): 85-89.

Tiwari, R.B., Singh, Parihar (2003). Role of Front Line Demonstration in transfer of gram production technology. Maharashtra Journal of Extension Education, 22(1):19.

Tomar, L.S., Sharma, P.B. and Joshi, K. (2003). Study on yield gap and adoption level of potato production technology in gird region. Maharashtra Journal of Extension Education, 22(1):15-18.

\section{How to cite this article:}

Singh, A.K., Mamta Singh, A.K. Tripathi and Yadav, K.S. 2019. Impact of Technological Demonstrations on Yield of Rabi Pulses and Farmer's Adoption Behavior in Vindhyan Plateau of Madhya Pradesh. Int.J.Curr.Microbiol.App.Sci. 8(02): 3094-3100. doi: https://doi.org/10.20546/ijcmas.2019.802.362 